\title{
Modern Diagnostics of Sepsis and Septic Shock in Children
}

\author{
Yekaterina Y. Bulatova ${ }^{1^{*}}$, Nurila A. Maltabarova ${ }^{1}$, Murat B. Zhumabayev ${ }^{1}$, Tatyana A. Li ${ }^{1}$, Marina P. Ivanova ${ }^{1}$
}

${ }^{1}$ NJSC “Astana Medical University”, 010000, Nur-Sultan, KAZAKHSTAN

*Corresponding Author: bulatovaekaterina782@gmail.com

Citation: Bulatova YY, Maltabarova NA, Zhumabayev MB, Li TA, Ivanova MP. Modern Diagnostics of Sepsis and Septic Shock in Children. Electron J Gen Med. 2020;17(5):em216. https://doi.org/10.29333/ejgm/7879

\section{ARTICLE INFO}

Received: 17 Jan. 2020

Accepted: 24 Feb. 2020

\begin{abstract}
Sepsis is still one of the leading causes of child mortality worldwide, despite advances in its diagnosis and treatment. Difficulties in recognizing the transition of a localized infectious-inflammatory process to a generalized one lead to a belated diagnosis and the beginning of therapy. Meanwhile, the earlier treatment is started, the higher the patients' chances of life. Early diagnosis of sepsis, which corresponds to modern ideas about this condition, is one of the main tasks for both scientists and practitioners. The aim of this review is to study modern recommendations for the diagnosis of sepsis and septic shock in children. The article reflects the epidemiology, etiological features, modern definitions and methods of diagnosis of pediatric sepsis.
\end{abstract}

Keywords: sepsis in children, pediatric sepsis, septic shock in children, sepsis diagnostics, sepsis recognition, sepsis biomarkers

\section{INTRODUCTION}

Sepsis is one of the leading causes of child mortality worldwide, despite the progress made in its study over the past decades (1,2). In 2017, the World Health Organization named sepsis as one of the priority tasks of healthcare in the coming decade (3,4). Clinically, sepsis is a syndrome that complicates the course of severe out-of-hospital and in-hospital infections and leads, in turn, to life-threatening conditions such as septic shock and multiple organ failure (5). The symptoms of sepsis are polymorphic and depend on many factors: the age of the child, its premorbid state, the infectious agent, the source of infection, and others. Currently sepsis is considered as a body regulation disorder of the normal protective response to infection and a serious role in its development is given to genetic factors (6-9). Thus, at this stage, it is difficult to predict whether a particular child will have an infectious disease with sepsis or not, and clinical polymorphism and the presence of the so-called "latent" course of sepsis create significant diagnostic difficulties. On the other hand, timely diagnosis of sepsis in children and, consequently, the earliest possible start of therapy is crucial for the prognosis of the disease. Delay of therapy even for 1 hour leads to an increase in mortality (5.10).

In accordance with the foregoing, the earliest possible diagnosis of the septic process in children is one of the main tasks for the clinician. Indeed, the sooner targeted treatment is started, which includes antibiotics and infusion therapy, the more chances there are to stop the development of sepsis (11).

It should be noted that in this article we did not aim to consider the features of sepsis in newborns, since sepsis in this age group differs significantly from sepsis in children older than the neonatal period and adults and requires separate consideration (12).

\section{RESEARCH MATERIALS AND METHODS}

Study of the literary sources collected in the databases of PubMed, ScienceDirect, Cochraine Library, search depth 10 years, from 2009 to 2019 was conducted, all types of articles were studied, key words: sepsis in children, pediatric sepsis, septic shock in children, sepsis diagnostics, sepsis recognition, sepsis biomarkers. As a result of a thorough scientific search, 62 articles were selected that, in our opinion, are of the greatest interest according to the chosen topic.

\section{MAIN PART}

\section{Epidemiology of Sepsis}

Assessing the global epidemiology of sepsis and septic shock in children presents certain difficulties related to economic and diagnostic factors. In recent years, several attempts have been made to estimate the worldwide incidence of pediatric sepsis. In 2014, the original study The Sepsis Prevalence, Outcomes and Therapies Study (SPROUT) was published, showing very interesting results. The study included 6925 children from 128 intensive care units from North America, Europe, Asia, Australia and New Zealand, South America and Africa. The average incidence of severe sepsis was $8.2 \%$, but it certainly varied from $6.2 \%$ in Europe to $23.1 \%$ in Africa. At the same time, the mortality rate from this pathology in all the studied countries was approximately the same and amounted to $23-24 \%$. It is also interesting that the majority of patients $(77 \%)$ were diagnosed with concomitant diseases, among which the most common were respiratory disorders. 
The most common foci of infection were the respiratory system (40\%) and blood flow (19\%) (1,13-15).

A detailed review of 2019 showed the following results: in countries with a high level of economic development, the prevalence of severe sepsis ranged widely from $1.4 \%$ in Japan to $7.7 \%$ in the United States, the mortality rate from severe sepsis was $7-17 \%$, from septic shock to $51 \%$. In developing countries, the incidence of severe sepsis among children also varied from $1 \%$ to $25.9 \%$, and the mortality rate was 12.3 $34.6 \%$. The authors attribute these significant fluctuations to various diagnostic criteria and economic factors $(16,17)$.

Currently, there are no clear and unambiguous criteria for diagnosing sepsis in children in the Republic of Kazakhstan. The statistical collection of population health of the Republic of Kazakhstan contains the following data: the incidence of sepsis in children under 1 year was 7 children out of 1000 in 2016, 21 children out of 1000 in 2017, the death rate from sepsis was registered only for neonatal sepsis and amounted to 3.88 per 10,000 children born alive (18).

It should also be noted that, according to research, most cases of sepsis occur before the age of 3 years, which can probably be associated with the anatomical and physiological characteristics of young children $(11,19,20)$. Children with chronic comorbidities had a higher mortality rate $(21,22)$.

\section{Etiology of Sepsis}

Infectious agents that lead to septic complications in children differ from those in adults. Bacteria and viruses most often cause sepsis. For children older than the neonatal age is the most common causative agents are Streptococcus, Staphylococcus, Meningococcus, and Pseudomonas. Streptococcus pneumoniae most often leads to sepsis among toddlers and young children. It should also be noted the important role of Haemophilus influenzae in the development of sepsis in countries where there is no active vaccination against this infection. A special place is occupied by nosocomial and multi-resistant to antibacterial drugs microorganisms. Among hospital infections, gram-negative bacteria - Pseudomonas aeruginosa, Klebsiella species, E. coli, Acinetobacter species, and Salmonella spp - most often lead to sepsis. Catheter-associated sepsis is caused by coagulasenegative staphylococci $(6,19,20,23)$.

It is necessary to take into account the possibility of participation of other microorganisms in the development of sepsis - viruses and fungi. According to the literature, the prevalence of viral and mycotic septic complications in the child population is $2.9-5.3 \%$. Among viral infections, influenza, parainfluenza, adenovirus infection, CMV infection, and herpes are most often complicated by sepsis $(24,25)$.

Fungal infections usually lead to septic complications in children with concomitant immunodeficiency and the need for invasive manipulations. Among the pathogens of mycosis, sepsis is most often caused by Candida species, Candida albicans, and Aspergillus species.

In patients with immunodeficiency disorders of various etiologies, sepsis may be caused by opportunistic microorganisms (25).

It should be noted that it is not always possible to identify the pathogen in the hemoculture. According to current data, the pathogen remains unknown in $30-75 \%$ of children with sepsis $(25,26)$.

\section{Definitions of Sepsis and Septic Shock in Children}

The active study of sepsis and its complications continues all over the world, and new data on pathophysiology, microbiology, and clinical disciplines are accumulating, which contributes to changing the current understanding of this condition. If earlier the leading role in the development of sepsis was given to an infectious agent, then gradually the pathological reaction of the macroorganism came to the fore, that is, a generalized inflammatory response combined with damage to various organs and systems. Thus, there was a fundamentally new understanding of sepsis, approaches to its diagnosis and treatment.

According to the original concept of the American College Consensus Conference of pulmonologists and Society of Critical Care Medicine ACCP/SCCM, 1991, basis of sepsis development was considered to be systemic inflammatory reaction syndrome in response to infectious aggression. In order to diagnose sepsis, the criteria for systemic inflammatory response syndrome (SIRS) were developed, which clinicians have relied on for a long time in their work. However, it has now been established that the response of the human body to a microbial agent is a much more complex and multi-faceted process in which not only the immune system, but also other organ systems are actively involved, as well as genetic characteristics, gender, age, race, concomitant conditions, and therapy (27-30). Due to these factors, the clinical picture of sepsis is characterized by pronounced polymorphism, which makes it very difficult to diagnose it early.

It should also be noted that the results of the conducted studies indicate a low specificity of SIRS criteria in the diagnosis of sepsis. SIRS develops in most patients of the intensive care unit (ICU) against a variety of conditions and, in principle, does not indicate the etiology of the disease. In addition, the existence of SIRS-negative sepsis has now been proven. In this case, sepsis develops without prior development of systemic inflammation, respectively, according to the ACCP/SCCM criteria, such children cannot be classified as patients with sepsis (31).

Thus, on the one hand, the concept of sepsis ACCP/SCCM was an important step towards studying the problem of sepsis and set a further direction for the search, on the other hand, it left a lot of questions.

In 2005, the results of the International Pediatric Sepsis Consensus Conference (IPSCC-2005) were published. Criteria for systemic inflammatory response syndrome and definition of sepsis in children were developed based on criteria for adults, taking into account the anatomical and physiological characteristics of children of different age groups (32).

In 2016, new consensus definitions of sepsis and septic shock were published, called "The Third International Consensus on the definition of sepsis and septic shock ("Sepsis-3")", authored by experts from the Society Critical Care Medicine (SCCM), European Society Intensive Care Medicine (ESICM). According to new data, sepsis is considered as a dysregulation of the body response to the infectious process with the development of organ dysfunction. At the same time, the concept does not deny the participation of systemic inflammation in the septic process, but considers it as one of the possible variants of the body response to infection (27). 
Table 1. Definitions of sepsis in children, IPSSC-2005 (32)

\section{SIRS}

The presence of at least two of the following four criteria, one of which is necessarily an abnormal temperature or number of white blood cells - central temperature $>38.5 \mathrm{C}$ or $<36.0 \mathrm{C}$

- tachycardia, defined as a heart rate exceeding 2 square deviations from the age norm in the absence of external stimuli; for children less than 1 year - bradycardia, defined as a heart rate less than the 10th age percentile in the absence of external stimuli; or unexplained hemodynamic depression lasting more than half an hour

- respiration rate exceeding 2 square deviations from the age norm or the need for a ventilator in an acute process that is not associated with neuromuscular diseases or general anesthesia

- the number of white blood cells increased or decreased in comparison with the age norm, in the absence of chemotherapy, or immature neutrophils $>10 \%$

Infection

Suspected or proven by detecting a pathogen in the internal environment, caused by any pathogen, or clinical syndromes associated with a high probability of infection

Sepsis

SIRS in the presence of a proven or suspected infection

Severe sepsis

Sepsis + one of the following: cardiovascular organ dysfunction, acute respiratory distress syndrome, two or more dysfunctions of other organs and systems

Septic shock

Sepsis + cardiovascular organ dysfunction

Table 2. Definitions of sepsis according to the concept "Sepsis-3" (27)

\begin{tabular}{ll}
\hline Definition & $\begin{array}{l}\text { Sepsis is a life-threatening acute organ dysfunction that occurs as a result of a disorder of the regulation of the } \\
\text { macroorganism's response to infection }\end{array}$ \\
\hline Pathophysiological diagnostics & $\begin{array}{l}\text { Disorder of the regulation of the macroorganism's response to infection is manifested by damage to its own } \\
\text { tissues and organs }\end{array}$ \\
\hline Criteria of sepsis & $\begin{array}{l}\text { Suspected or documented infection in combination with acute organ dysfunction, the development of which } \\
\text { is concluded on the index of the SOFA scale by } 2 \text { points or more from the base value }\end{array}$ \\
\hline Septic shock & $\begin{array}{l}\text { A clinical variant of the course of sepsis characterized by circulatory insufficiency, which is manifested by } \\
\text { arterial hypotension, an increase in the level of lactate more than } 2 \text { mmol/l, despite adequate infusion, and } \\
\text { requiring the administration of vasopressors to maintain normal blood pressure }\end{array}$ \\
\hline
\end{tabular}

\section{Modern Diagnostics of Sepsis and Septic Shock in Children}

There are several fundamentally important differences in the development of the body response to infection, which clearly distinguish between pediatric sepsis and adult sepsis. Age-related differences in the concentration and composition of hemoglobin, heart rate, stroke volume, blood pressure, pulmonary vascular resistance, systemic vascular resistance, metabolic rate, glycogen stores, and protein mass are the basis of many age-related differences in the body response to infection (33-36). Thus, the principles of sepsis diagnosis developed for adults are not suitable for children.

Modern diagnostics of sepsis, as well as its complications septic shock and multiple organ failure - in children is based on the recommendations of IPSCC-2005 and "Sepsis-3". Diagnostic measures can be divided into two groups: clinical diagnostics and laboratory-instrumental methods. Despite the large number of different laboratory markers of systemic inflammation and sepsis, most researchers now agree that the priority belongs to clinical signs. This can be attributed to the lack of a universal marker that would be sensitive to all types of infection, detect sepsis, at the earliest stages, in different children and would be financially available in any clinic in the world. As mentioned above, sepsis is a condition characterized by clinical polymorphism, but it has certain pathophysiological stages of development that can be traced in the patient's condition.

In accordance with the concept of IPSCC-2005, sepsis begins with a systemic inflammatory reaction, for the diagnosis of which certain criteria were proposed, adapted to children of different age groups.
Age groups of children with sepsis, IPSCC-2005 (32)

1. Early neonatal period (0-7 days)

2. Late neonatal period (8-28 days)

3. Infant age ( 29 days- 1 year)

4. Preschool age (1-5 years)

5. School age (6-12 years)

6. Adolescence (13-18 years)

Systemic inflammation develops not only as a result of infection, but also in other conditions (injuries, acute pancreatitis, in the postoperative period, etc.), since it is essentially a non-specific reaction of the body to damage $(37,38)$. This reduces its diagnostic value in sepsis. In accordance with the concept "Sepsis-3", the main manifestation of sepsis is organ dysfunction, which is recommended to determine in the ICU using the Pediatric Sequential Organic Failure Score (pSOFA).

The advantages of the scale include high specificity and sensitivity in relation to children in the intensive care unit (39). On the other hand, the scale is aimed at predicting the outcome of the disease, rather than diagnosing sepsis at the early stages of its development, when there are no pronounced signs of multiple organ failure; in addition, the scale requires daily biochemical studies, which is not always possible and not always safe for the patient, especially for young children. Thus, the search for a better tool for timely diagnosis of sepsis continues $(40,41)$.

At the same time, there is no doubt that the concept of multiple organ failure as a leading link in pathogenesis is an important step towards improving the management of sepsis in children and adults. 
Table 3. Systemic inflammatory reaction syndrome in children, IPSCC-2005 (32)

\begin{tabular}{|c|c|c|c|c|c|}
\hline \multirow{2}{*}{ Age } & \multicolumn{2}{|c|}{ Heart rate } & \multirow[b]{2}{*}{$\mathrm{RR}$} & \multirow{2}{*}{ Leukocytes, * $10^{9} / \mathrm{l}$} & \multirow{2}{*}{$\begin{array}{c}\text { Systolic blood } \\
\text { pressure, } \mathrm{mm} \mathrm{Hg}\end{array}$} \\
\hline & Bradycardia & Tachycardia & & & \\
\hline $0-7$ days & $<100$ & $>180$ & $>50$ & $>34000$ & $<65$ \\
\hline 8-28 days & $<100$ & $>180$ & $>40$ & $>19500$ or $<5000$ & $<75$ \\
\hline 28 days- 1 year & $<90$ & $>180$ & $>34$ & $>17500$ or $<5000$ & $<100$ \\
\hline $1-5$ years & - & $>140$ & $>22$ & $>15500$ or $<6000$ & $<94$ \\
\hline $6-12$ years & - & $>130$ & $>18$ & $>13500$ or $<4500$ & $<105$ \\
\hline 13-18 years & - & $>110$ & $>14$ & $>11000$ or $<4500$ & $<117$ \\
\hline
\end{tabular}

Table 4. Scale of diagnosis of multiple organ dysfunction in children with pSOFA sepsis (27)

\begin{tabular}{|c|c|c|c|c|c|c|}
\hline \multirow[t]{2}{*}{ № } & \multirow[t]{2}{*}{ Criteria } & \multicolumn{5}{|c|}{ Points } \\
\hline & & 0 & 1 & 2 & 3 & 4 \\
\hline \multirow[t]{2}{*}{1} & $\mathrm{PaO2} / \mathrm{FiO} 2$ or & $\geq 400$ & $300-399$ & $200-299$ & 100-199 ALV & $<100 \mathrm{ALV}$ \\
\hline & $\mathrm{SpO} 2 / \mathrm{FiO} 2$ & $\geq 292$ & $264-291$ & $221-263$ & $148-220$ ALV & $<148$ ALV \\
\hline 2 & Platelets & $\geq 150$ & $100-149$ & $50-99$ & $20-49$ & $<20$ \\
\hline 3 & Bilirubin, $\mathrm{mg} / \mathrm{dL}$ & $<1,2$ & $1,2-1,9$ & $2,0-5,9$ & $6,0-11,9$ & $\geq 12$ \\
\hline \multirow[t]{7}{*}{4} & Average blood pressure & & & Dopamine or & Dopamine $>5$ & Dopamine $>15$ \\
\hline & Less than 1 month & $\geq 46$ & $<46$ & dobutamine 5 & $\mu \mathrm{g} / \mathrm{kg} / \mathrm{min}$ or & $\mu \mathrm{g} / \mathrm{kg} / \mathrm{min}$ or \\
\hline & 1-11 months & $\geq 55$ & $<55$ & & $\begin{array}{c}\text { epinephrine, } \\
\text { norepinephrine } \leq 0.1\end{array}$ & $\begin{array}{c}\text { epinephrine, } \\
\text { norepinephrine }>0.1\end{array}$ \\
\hline & $1-2$ years & $\geq 60$ & $<60$ & & $\mu \mathrm{g} / \mathrm{kg} / \mathrm{min}$ & $\mu \mathrm{g} / \mathrm{kg} / \mathrm{min}$ \\
\hline & $2-5$ years & $\geq 62$ & $<62$ & & & \\
\hline & $5-12$ years & $\geq 65$ & $<65$ & & & \\
\hline & $12-18$ years & $\geq 67$ & $<67$ & & & \\
\hline 5 & GCS & 15 & 13-14 & $10-12$ & $6-9$ & $<6$ \\
\hline \multirow[t]{7}{*}{6} & Creatinine, $\mathrm{mg} / \mathrm{dL}$ & & & & & \\
\hline & Less than 1 month & $<0,8$ & $0,8-0,9$ & $1,0-1,1$ & $1,2-1,5$ & $\geq 1,6$ \\
\hline & 1-11 months & $<0,3$ & $0,3-0,4$ & $0,5-0,7$ & $0,8-1,1$ & $\geq 1,2$ \\
\hline & $1-2$ years & $<0,4$ & $0,4-0,5$ & $0,6-1,0$ & $1,1-1,4$ & $\geq 1,5$ \\
\hline & 2-5 years & $<0,6$ & $0,6-0,8$ & $0,9-1,5$ & $1,6-2,2$ & $\geq 2,3$ \\
\hline & $5-12$ years & $<0,7$ & $0,7-1,1$ & $1,1-1,7$ & $1,8-2,5$ & $\geq 2,6$ \\
\hline & $12-18$ years & $<1,0$ & $1,0-1,6$ & $1,7-2,8$ & $2,9-4,1$ & $\geq 4,2$ \\
\hline
\end{tabular}

\section{Septic Shock in Children}

Septic shock in a child is considered as severe hemodynamic disorders that complicate the course of sepsis. It should be noted that the clinical manifestations of septic shock in children differ from those in adults due to age-related features of the circulatory system. It is important to remember that arterial hypotension in children of the first years of life appears only at the later stages of shock development. Focusing only on blood pressure, the doctor risks missing the development of septic shock. It is known that the main compensatory mechanism of hemodynamics in young children is an increase in heart rate, so tachycardia is one of the most significant signs in shock in a young child. Pathogenetic mechanisms of septic shock lead to a disorder of microhemodynamics, which can be seen clinically by evaluating the time of capillary filling. Disorder of microhemodynamics leads to tissue hypoxia, which manifests itself as a significant increase in the concentration of lactate in the blood plasma. Thus, the main signs indicating septic shock in a child should not be considered a decrease in blood pressure, but signs of impaired tissue perfusion and tachycardia - as an attempt by the body to compensate for hemodynamic disorders $(32,42)$.

Criteria for cardiovascular dysfunction (after infusion of at least $40 \mathrm{ml} / \mathrm{kg}$ ), IPSCC-2005 (32)
- arterial hypotension - decreased systolic pressure $<2$ SD or the need to use vasopressors, or 2 criteria:

- unexplained metabolic acidosis with base deficiency > $5 \mathrm{mEq} / \mathrm{L}$;

- lactate acidosis: serum lactate > 2 norms;

- oliguria (<0.5 ml/kg/hour);

- symptom of a "white spot" (a spot that appears when pressing your finger on the skin over the III-IV metatarsal bones of the patient lying on his back) $>5 \mathrm{~s}$;

- difference between central and peripheral temperature $>3^{\circ} \mathrm{C}$.

\section{Specific Diagnosis of Sepsis and Septic Shock in Children}

Numerous laboratory biomarkers are used to clarify the diagnosis of sepsis and septic shock. Seroreactive protein (CRP) and procalcitonin (PCT) are the most commonly used in clinical practice. CRP is recommended to be used in combination with $\mathrm{PCT}$, together they have shown high efficiency in recognizing severe bacterial infection in young children with long-term fever, as well as in neutropenia. Isolated use of CRP is not recommended (43).

According to research, PCT is a valuable diagnostic marker for sepsis caused by bacterial infection in children. It should be noted that the concentration of PCT may increase in noninfectious conditions, which limits its use (44). 
Presepsin is an effective biochemical marker of sepsis, the mechanism of which is different from the mechanism of increasing CRP, PCT, and other markers. The level of presepsin increases quickly when the infection generalizes, and also quickly shows a positive trend. According to a recent metaanalysis, presepsin showed high sensitivity and diagnostic accuracy in sepsis in children compared to CRP and PCT, but its specificity was lower. There was also a significant increase in presepsin concentration in children with suspected or registered catheter-associated infection compared to healthy children in the control group (45-47).

The level of cytokines in the blood increases early in the infectious process, which allows them to be used as markers of systemic inflammation and sepsis. According to different authors, the concentration of IL- 6 in serum in children with sepsis differs significantly from its concentration in healthy children $(25,48)$.

Lactate is used to diagnose septic shock and evaluate its therapy, but evidence for its effectiveness in children is limited. Studies have shown that the concentration of lactate in blood plasma in children more than $4 \mathrm{mmol} / \mathrm{l}$ is associated with the development of multiple organ failure in the next 24 hours, but in $4 \%$ of cases, multiple organ failure developed in children with a lactate level less than $4 \mathrm{mmol} / \mathrm{l}$. Therefore, normal or slightly elevated levels of lactate in blood plasma do not exclude the development of severe sepsis and septic shock $(49,50)$.

Pentraxin 3 significantly increases in critically ill children, including those with sepsis, but there was no difference in the concentration of pentraxin 3 between critically ill children with sepsis and other diagnoses. Thus, pentraxin 3 is more of a marker of systemic inflammation than of sepsis (46).

In recent years, The Pediatric Sepsis Biomarker Risk Model (PERSEVERE, PERSEVERE II, and PERSEVERE-XP) biomarker panels based on patient genome studies have been developed to identify the risk of death in septic shock in children. PERSEVERE biomarkers are generally associated with inflammation and cellular damage, which makes it highly likely to identify the risk of deterioration in a particular child with septic shock (51-53).

There are also separate studies that prove the diagnostic effectiveness in pediatric sepsis of indicators of hemostasis, leucoformula, adapted to the age characteristics of the "shock index" (54-57).

It should be noted that currently no set of biomarkers can reliably detect the presence of sepsis in a child, and PERSEVERE panels require special equipment and are aimed only at recognizing septic shock in ICU conditions, so the use of laboratory studies should always be based on the clinical picture $(58,59)$.

\section{CONCLUSION}

It should be noted that much has been done in the study of pediatric sepsis in recent years $(60,61)$. In general, child mortality in the world has decreased significantly in recent years, including through the use of common methods of diagnosis and treatment confirmed by numerous studies (62). The mainstreaming of modern diagnostic methods should significantly reduce the mortality from sepsis and its complications in children due to earlier and better recognition of this process.

Despite the undoubted success in the study of sepsis, there are still a number of urgent problems, especially typical for pediatrics. First, the systemic inflammatory response syndrome cannot be the only basis for diagnosing sepsis. Second, diagnosis of sepsis using the pSOFA scale in children requires the presence of obvious organ dysfunction, which delays treatment. Third, the pSOFA scale, like other similar scales, was created to assess the severity of the patient's condition and predict death, not to diagnose sepsis. The scale requires daily laboratory tests, which may not be available in real clinical settings and require frequent blood sampling, including in very young children.

\section{REFERENCES}

1. Dugani S, Kissoon N. Global advocacy needed for sepsis in children. Journal of Infection, 2017:74. https://doi.org/ 10.1016/s0163-4453(17)30193-7

2. Schlapbach LJ, Straney L, Alexander J, Maclaren G, Festa M, Schibler A, Slater A. Mortality related to invasive infections, sepsis, and septic shock in critically ill children in Australia and New Zealand, 2002-13: a multicentre retrospective cohort study. The Lancet Infectious Diseases, 2015;15(1):46-54. https://doi.org/10.1016/s1473-3099(14) 71003-5

3. Fleischmann-Struzek C, Goldfarb DM, Schlattmann P, Schlapbach LJ, Reinhart K, Kissoon N. The global burden of paediatric and neonatal sepsis: a systematic review. The Lancet Respiratory Medicine, 2018;6(3):223-30. https://doi.org/10.1016/S2213-2600(18)30063-8

4. Ansermino JM, Wiens MO, Kissoon N. We need smarter trigger tools for diagnosing sepsis in children in Canada. Cmaj, 2018;190(36):E1060-E1061. https://doi.org/10.1503/ cmaj.180434 PMid:30201612 PMCid:PMC6131073

5. Conway EE. Pediatric Sepsis: A Primer for the Pediatrician. Pediatric Annals, 2018;47(7):e292-e299. https://doi.org/ 10.3928/19382359-20180620-02 PMid:30001444

6. Agyeman PKA, Schlapbach LJ, Giannoni E, Stocker M, Posfay-Barbe KM, et al. Epidemiology of blood cultureproven bacterial sepsis in children in Switzerland: a population-based cohort study. The Lancet Child \& Adolescent Health, 2017;1(2):124-33. https://doi.org/ 10.1016/S2352-4642(17)30010-X

7. Yang J, Zhang S, Zhang J, Dong J, Wu J, Zhang L, et al. Identification of key genes and pathways using bioinformatics analysis in septic shock children. Infection and Drug Resistance, 2018;11:1163-74. https://doi.org/ 10.2147/IDR.S157269 PMid:30147344 PMCid:PMC6098424

8. Wong HR. Genetics and genomics in pediatric septic shock. Critical Care Medicine, 2012;40(5):1618-26. https://doi.org/ 10.1097/CCM.0b013e318246b546 PMid:22511139 PMCid:PMC3329642

9. Seymour CW, Liu VX, Iwashyna TJ, Brunkhorst FM, Rea TD, et al. Assessment of Clinical Criteria for Sepsis: For the Third International Consensus Definitions for Sepsis and Septic Shock (Sepsis-3). JAMA, 2016;315(8):762-74. https://doi.org/10.1001/jama.2016.0288 PMid:26903335 PMCid:PMC5433435 
10. Bradshaw C, Goodman I, Rosenberg R, Bandera C, Fierman A, Rudy B. Implementation of an inpatient pediatric sepsis identification pathway. Pediatrics, 2016;137(3). https://doi.org/10.1542/peds.2014-4082 PMid:26908676

11. Ames SG, Davis BS, Angus DC, Carcillo JA, Kahn JM. Hospital Variation in Risk-Adjusted Pediatric Sepsis Mortality. Pediatric Critical Care Medicine: A Journal of the Society of Critical Care Medicine and the World Federation of Pediatric Intensive and Critical Care Societies, 2018;19(5):390-6. https://doi.org/10.1097/PCC.0000000000 001502 PMid:29461429 PMCid:PMC5935525

12. Mathias B, Mira JC, Larson SD. Pediatric sepsis. Current Opinion in Pediatrics, 2016;28(3):380-7. https://doi.org/ 10.1097/MOP.0000000000000337 PMid:26983000 PMCid:PMC4913352

13. Weiss SL, Fitzgerald JC, Pappachan J, Wheeler D, JaramilloBustamante JC, Salloo A. Sepsis Prevalence, Outcomes, and Therapies (SPROUT) Study Investigators and Pediatric Acute Lung Injury and Sepsis Investigators (PALISI) Network. Global epidemiology of pediatric severe sepsis: the sepsis prevalence, outcomes, and therapies study. American Journal of Respiratory and Critical Care Medicine, 2015;191(10):1147-57. https://doi.org/10.1164/rccm.20141 2-23230C PMid:25734408 PMCid:PMC4451622

14. Plunkett A, Tong J. Sepsis in children. BMJ, 2015;350(jun09 10):h3017-h3017. https://doi.org/10.1136/bmj.h3017 PMid:26060188

15. Souza DCde, Brandão MB, Piva JP. From the International Pediatric Sepsis Conference 2005 to the Sepsis-3 Consensus. Revista Brasileira de Terapia Intensiva, 2018;30(1):1-5. https://doi.org/10.5935/0103-507x.201800 05

16. de Souza D, Machado F. Epidemiology of Pediatric Septic Shock. Journal of Pediatric Intensive Care, 2019;08(01):00310.https://doi.org/10.1055/s-0038-1676634 PMid:31073502 PMCid:PMC6506671

17. Tan B, Wong JJM, Sultana R, Koh JCJW, Jit M, Mok YH, Lee JH. Global Case-Fatality Rates in Pediatric Severe Sepsis and Septic Shock: A Systematic Review and Meta-analysis. JAMA Pediatrics, 2019, April 1;173:352-61. https://doi.org/ 10.1001/jamapediatrics.2018.4839 PMid:30742207 PMCid:PMC6450287

18. The Ministry of Health Care of The Republic of Kazakhstan. The health of the population of the Republic of Kazakhstan and the activities of healthcare organizations in 2017. Statistical Digest. Astana, Republic of Kazakhstan. 2018.

19. Boeddha NP, Schlapbach LJ, Driessen GJ, Herberg JA, Rivero-Calle I, Cebey-López M. EUCLIDS consortium, on behalf of the $\mathrm{E}$. Mortality and morbidity in communityacquired sepsis in European pediatric intensive care units: a prospective cohort study from the European Childhood Life-threatening Infectious Disease Study (EUCLIDS). Critical Care (London, England), 2018;22(1):143. https://doi.org/10.1186/s13054-018-2052-7 PMid:29855385 PMCid:PMC5984383

20. Hasan GM, Al-Eyadhy AA, Temsah MHA, Al-Haboob AA, Alkhateeb MA, Al-Sohime F. Feasibility and efficacy of sepsis management guidelines in a pediatric intensive care unit in Saudi Arabia: A quality improvement initiative. International Journal for Quality in Health Care, 2018;30(8):587-93. https://doi.org/10.1093/intqhc/mzy077 PMid:29697828
21. Prout AJ, Talisa VB, Carcillo JA, Mayr FB, Angus DC, Seymour CW, et al. Children with Chronic Disease Bear the Highest Burden of Pediatric Sepsis. The Journal of Pediatrics, 2018;199:194-199.e1. https://doi.org/10.1016/ j.jpeds.2018.03.056 PMid:29753542 PMCid:PMC6063765

22. Ruth A, McCracken CE, Fortenberry JD, Hall M, Simon HK, \& Hebbar KB. Pediatric severe sepsis: Current trends and outcomes from the pediatric health information systems database. Pediatric Critical Care Medicine, 2014;15(9):82838. https://doi.org/10.1097/PCC.0000000000000254 PMid:25226500

23. Kuo K-C, Yeh Y-C, Chiu I-M, Tang K-S, Su C-M, Huang Y-H. The clinical features and therapy of community-acquired gram negative bacteremia in children less than three years old. Pediatrics \& Neonatology. 2019. https://doi.org/ 10.1016/j.pedneo.2019.05.009 PMid:31257100

24. Gupta N, Richter R, Robert S, Kong M. Viral Sepsis in Children. Frontiers in Pediatrics, 2018;6:252. https://doi.org/10.3389/fped.2018.00252 PMid:30280095 PMCid:PMC6153324

25. Donna Mendez RL. Sepsis in children. Pediatrics International, 2000;42(5):528-33. https://doi.org/10.1046/ j.1442-200X.2000.01281.x PMid:11059544

26. Hartman ME, Linde-Zwirble WT, Angus DC, Watson RS. Trends in the epidemiology of pediatric severe sepsis. Pediatric Critical Care Medicine, 2013;14(7):686-93. https://doi.org/10.1097/PCC.0b013e3182917fad PMid:23897242

27. Seymour CW, Liu VX, Iwashyna TJ, Brunkhorst FM, Rea TD, Scherag A, et al. Assessment of Clinical Criteria for Sepsis: For the Third International Consensus Definitions for Sepsis and Septic Shock (Sepsis-3). JAMA, 2016;315(8):762-74. https://doi.org/10.1001/jama.2016.0288 PMid:26903335 PMCid:PMC5433435

28. Weiss SL, Deutschman CS. Are septic children really just "septic little adults"? Intensive Care Medicine, 2018;44(3):392-4. https://doi.org/10.1007/s00134-0175041-4 PMid:29356850

29. Simpson SQ. SIRS in the Time of Sepsis-3. Chest, 2018;153(1):34-8. https://doi.org/10.1016/j.chest.2017.10. 006 PMid:29037526

30. Sankar J, Dhochak N, Kumar K, Singh M, Sankar MJ, Lodha R. Comparison of International Pediatric Sepsis Consensus Conference Versus Sepsis-3 Definitions for Children Presenting with Septic Shock to a Tertiary Care Center in India: A Retrospective Study*. Pediatric Critical Care Medicine, 2019;20(3):E122-E129. https://doi.org/10.1097/ PCC.0000000000001864 PMid:30640887

31. Wang $Y$, Lin $X$, Yue $H$, Kissoon $N$, Sun B. Evaluation of systemic inflammatory response syndrome-negative sepsis from a Chinese regional pediatric network 11 Medical and Health Sciences 1103 Clinical Sciences. BMC Pediatrics, 2019;19(1). https://doi.org/10.1186/s12887-0181364-8 PMid:30621637 PMCid:PMC6325779

32. Goldstein B, Giroir B, Randolph A. International pediatric sepsis consensus conference: Definitions for sepsis and organ dysfunction in pediatrics. Pediatric Critical Care Medicine, 2005;6(1). https://doi.org/10.1097/01.PCC. 0000149131.72248.E6 PMid:15636651

33. Dellinger RP, Levy MM, Rhodes A, Annane D, Gerlach H, Opal $\mathrm{SM}$, et al. Surviving sepsis campaign: International guidelines for management of severe sepsis and septic shock, 2012. Intensive Care Medicine. 2013. https://doi.org/ 10.1007/s00134-012-2769-8 PMid:23361625 
34. Emr BM, Alcamo AM, Carcillo JA, Aneja RK, Mollen KP. Pediatric Sepsis Update: How Are Children Different? Surgical Infections, 2018;19(2):176-83. https://doi.org/ 10.1089/sur.2017.316 PMid:29394150

35. Wheeler DS, Wong HR, Zingarelli B. Pediatric Sepsis - Part I: "Children are not small adults"; The Open Inflammation Journal, 2011;4:4-15. https://doi.org/10.2174/ 1875041901104010004 PMid:23723956 PMCid:PMC3665507

36. Wheeler DS. Introduction to Pediatric Sepsis. The Open Inflammation Journal, 2011;4(Suppl 1-M):1-3. https://doi.org/10.2174/1875041901104010001 PMid:25285177 PMCid:PMC4183156

37. Horeczko T, Green JP. Emergency department presentation of the pediatric systemic inflammatory response syndrome. Pediatric Emergency Care, 2013;29(11):1153-8. https://doi.org/10.1097/PEC.0b013e31 82a9e629 PMid:24168885

38. Zhumabayev M, Maltabarova N, Kokoshko A. A Cerebralstroke and the Problem of Inflammatory Complications. Research Journal of Medical Sciences, 2016;10(5):492-7. https://doi.org/10.36478/rjmsci.2016. 492.497

39. Schlapbach LJ, Straney L, Bellomo R, MacLaren G, Pilcher D. Prognostic accuracy of age-adapted SOFA, SIRS, PELOD2, and qSOFA for in-hospital mortality among children with suspected infection admitted to the intensive care unit. Intensive Care Medicine, 2018;44(2):179-88. https://doi.org /10.1007/s00134-017-5021-8 PMid:29256116 PMCid:PMC5816088

40. Schlapbach LJ. Paediatric sepsis. Current Opinion in Infectious Diseases, 2019:1. https://doi.org/10.1097/ QCO.0000000000000583 PMid:31335441

41. Peters C, Murthy S, Brant R, Kissoon N, Görges M. Mortality Risk Using a Pediatric Quick Sequential (Sepsis-Related) Organ Failure Assessment Varies With Vital Sign Thresholds. Pediatric Critical Care Medicine, 2018;19(8):e394-e402. https://doi.org/10.1097/PCC.000000 0000001598 PMid:29939978

42. Morin L, Ray S, Wilson C, Remy S, Benissa MR, Jansen NJG, et al. Refractory septic shock in children: a European Society of Paediatric and Neonatal Intensive Care definition. Intensive Care Medicine, 2016;42(12):1948-57. https://doi.org/10.1007/s00134-016-4574-2 PMid:27709263 PMCid:PMC5106490

43. Hofer N, Zacharias E, Müller W, Resch B. An update on the use of $\mathrm{C}$-reactive protein in early-Onset neonatal sepsis: Current insights and new tasks. Neonatology, 2012;102:2536. https://doi.org/10.1159/000336629 PMid:22507868

44. Martinez R, Rode H. Role of procalcitonin in paediatric burn wound sepsis. South African Medical Journal, 2018;108(10):793-4. https://doi.org/10.7196/SAMJ.2018.v1 08i10.13515 PMid:30421701

45. Tanır Basaranoglu S, Karadag-Oncel E, Aykac K, Ozsurekci $\mathrm{Y}$, Aycan AE, Cengiz AB, et al. Presepsin: A new marker of catheter related blood stream infections in pediatric patients. Journal of Infection and Chemotherapy, 2018;24(1):25-30. https://doi.org/10.1016/j.jiac.2017.08. 012 PMid:28919353

46. El Gendy FM, El-Mekkawy MS, Saleh NY, Habib MSEdin, Younis FE. Clinical study of Presepsin and Pentraxin3 in critically ill children. Journal of Critical Care, 2018;47:36-40. https://doi.org/10.1016/j.jcrc.2018.06.004 PMid:29886065
47. Yoon SH, Kim EH, Kim HY, Ahn JG. Presepsin as a diagnostic marker of sepsis in children and adolescents: A systemic review and meta-analysis. BMC Infectious Diseases, 2019;19(1). https://doi.org/10.1186/s12879-019-4397-1 PMid:31470804 PMCid:PMC6717384

48. Weidhase L, Wellhöfer D, Schulze G, Kaiser T, Drogies T, Wurst $U$, Petros S. Is Interleukin- 6 a better predictor of successful antibiotic therapy than procalcitonin and Creactive protein? A single center study in critically ill adults. BMC Infectious Diseases, 2019;19(1):150. https://doi.org/ 10.1186/s12879-019-3800-2 PMid:30760225 PMCid:PMC6375140

49. Casserly B, Phillips GS, Schorr C, Dellinger RP, Townsend $\mathrm{SR}$, Osborn TM, et al. Lactate measurements in sepsisinduced tissue hypoperfusion: results from the Surviving Sepsis Campaign database. Critical Care Medicine, 2015;43(3):567-73. https://doi.org/10.1097/CCM.00000000 00000742 PMid:25479113

50. Schuh AM, Leger KJ, Summers C, Uspal NG. Lactic Acidosis in a Critically III Patient: Not Always Sepsis. Pediatric Emergency Care, 2018;34(9):e165-e167. https://doi.org/ 10.1097/PEC.0000000000001603 PMid:30180106

51. Jacobs L, Berrens Z, Stenson EK, Zackoff MW, Danziger LA, Lahni P, Wong HR. The Pediatric Sepsis Biomarker Risk Model (PERSEVERE) Biomarkers Predict Clinical Deterioration and Mortality in Immunocompromised Children Evaluated for Infection. Scientific Reports, 2019;9(1). https://doi.org/10.1038/s41598-018-36743-z PMid:30675002 PMCid:PMC6344559

52. Wong HR, Cvijanovich NZ, Anas N, Allen GL, Thomas NJ, Bigham MT, et al. Improved risk stratification in pediatric septic shock using both protein and mRNA Biomarkers: Persevere-XP. American Journal of Respiratory and Critical Care Med, 2017;196(4):494-501. https://doi.org/10.1164/ rccm.201701-00660C PMid:28324661 PMCid:PMC5564676

53. Wong HR, Cvijanovich NZ, Anas N, Allen GL, Thomas NJ, et al. Pediatric Sepsis Biomarker Risk Model-II: Redefining the Pediatric Sepsis Biomarker Risk Model with Septic Shock Phenotype. Critical Care Medicine, 2016;44(11):2010-7. https://doi.org/10.1097/CCM.0000000000001852 PMid:27513537 PMCid:PMC5201138

54. Dursun A, Ozsoylu S, Akyildiz BN. Neutrophil-tolymphocyte ratio and mean platelet volume can be useful markers to predict sepsis in children. Pakistan Journal of Medical Sciences, 2018;34(4):918-22. https://doi.org/ 10.12669/pjms.344.14547

55. Gupta S, Alam A. Shock Index-A Useful Noninvasive Marker Associated With Age-Specific Early Mortality in Children With Severe Sepsis and Septic Shock: Age-Specific Shock Index Cut-Offs. Journal of Intensive Care Medicine, 2018:885066618802779. https://doi.org/10.1177/08850666 18802779 PMid:30278814

56. Sharma A, Sikka M, Gomber S, Sharma S. Plasma Fibrinogen and D-dimer in Children With Sepsis: A SingleCenter Experience. Iranian Journal of Pathology, 2018;13(2):272-5. Available at: http://www.ncbi.nlm.nih. gov/pubmed/30697298PMid:30697298PMCid:PMC6339482

57. Piva JP, Garcia PCR, Da Rocha TS. Hypofibrinogenemia and pediatric sepsis: Another piece of the puzzle! Pediatric Critical Care Medicine, 2018;19(5):491-2. https://doi.org/ 10.1097/PCC.0000000000001514 PMid:29727417 
58. A. Cabrita J, Pinheiro I, Menezes Falcão L. Rethinking the concept of sepsis and septic shock. European Journal of Internal Medicine, 2018, August 1;54:1-5. https://doi.org/10.1016/j.ejim.2018.06.002 PMid:29921471

59. Excellence C. Sepsis: recognition, diagnosis and early management: ( ) NICE (2017) Sepsis: recognition, diagnosis and early management. BJU International, 2018;121(4):497-514. https://doi.org/10.1111/bju.14179 PMid:29603898

60. Hébert A, Boucher M-P, Guimont C, Weiss M. Effect of measuring vital signs on recognition and treatment of septic children. Paediatrics \& Child Health, 2017;22(1):13-6. https://doi.org/10.1093/pch/pxw003 PMid:29483789 PMCid:PMC5819837
61. Gyawali B, Ramakrishna K, Dhamoon AS. Sepsis: The evolution in definition, pathophysiology, and management. SAGE Open Medicine, 2019;7:205031211983504. https://doi.org/10.1177/2050312 119835043 PMid:30915218 PMCid:PMC6429642

62. Li TA, Maltabarova NA, Kussaev YM, Yermekov JM. Bronchopulmonary Dysplasia at Children. Annals of Tropical Medicine \& Public Health-Special Issue, 2018;17:62-8. 